\title{
Imperial Scriptoria?
}

The discovery of the fragments in the ceiling of the Great mosque of Sanaa in 1972 led, as we have seen, to a momentous change in the historiography of the early Qur'anic manuscripts as well as in our knowledge of Umayyad art. ${ }^{1}$ Two illuminated pages facing each other at the beginning of a copy of impressive size caused a sensation and a discussion among specialists as to the age of this specific manuscript. In the aftermath of the short presentation by Marilyn Jenkins on the newly discovered fragments in the catalogue Mașăhif San' $\bar{a}^{3}, 2$ Hans-Caspar Von Bothmer published an important paper where he analysed in detail the ornaments of the twenty-five folios which were found and provided a codicological description based on a direct observation of the material. ${ }^{3} \mathrm{He}$ suggested an attribution to the last years of the reign of al-Walìd I, who reigned from $86 / 705$ to $96 / 715$.

However, historians of Islamic art expressed some doubts about the date of the copy and the idea that we actually had Umayyad manuscripts was scorned by some of them. Estelle Whelan published a paper which she intended as a first step in a demonstration of the supposedly mistaken attribution of the copy to the Umayyad period. ${ }^{4}$ She had rightly noted a close palaeographic relationship between Inv. 20-33.1 and Dublin, CBL Is 1404 (fig. 35) but reached the conclusion that the latter was from a later period. Although she avoided suggesting a date for the manuscript, she remarked that "no external evidence so far known ... permits a definitive attribution of any Qur'anic manuscript or group to a period earlier than the third/ninth century."5 Her views reflected a rather widely shared idea that no early copy of the Quran had survived. Comparing Is 1404 with a manuscript belonging to another palaeographic group with a strong connection with the third/ninth century, she strove to demonstrate that they "represent[ed] two distinct traditions of copying the

1 As already stressed by Hans-Caspar von Bothmer (Architekturbilder im Koran. Eine Prachthandschrift der Umayyadenzeit aus dem Yemen, Pantheon 45 [1987], p. 17).

2 M. Jenkins, A vocabulary of Umayyad ornament, in Mașāhif Șan' $\bar{a}^{\prime}$, Kuwait, 1985, pp. 19-23.

3 Hans-Caspar von Bothmer, op. cit., pp. 4-20.

4 E. Whelan, Writing the word of God I, Ars Orientalis 20 (1990), pp. 113-147. Her contribution was considered by Sheila Blair "the one that [she thinks] holds the most promise" (Islamic calligraphy, Edinburgh, 2006, p. 110).

5 Ibid., p. 124. 
Qur'an" which "[were] more consonant with production in two geographical centres"6 —instead of seeing each of them as representative of two periods.

Is 1404 (fig. 35) was kept in the Egyptian delta at the beginning of the twentieth century, when Bernhard Moritz saw it and published pictures of twelve of its illuminations in his Arabic palaeography. ${ }^{7}$ It was later acquired by Alfred Chester Beatty. ${ }^{8}$ The manuscript was in a very poor condition: it had been "restored" in a very crude way, with pieces of parchment and paper. ${ }^{9}$ Some of these repairs have been removed recently. In their present state, presumably after some trimming, the folios measure $47 \times 38 \mathrm{~cm}$ and are covered with 20 lines of text to the page. ${ }^{10}$ The writing surface covers $40,7 \times 32,5 \mathrm{~cm}$. In addition to the "repairs" of the support, both text and illuminations have been sometimes retraced, corrected or "enhanced" by later hands. It should be added that, according to a note in a late hand of the eighteenth century on the paste board of the binding, the copy was said to be 'Uthmān b. 'Affān's muṣhaf. ${ }^{11}$ Judging from the amount of text on a single folio, I estimate the original size of the

6 Ibid.

7 B. Moritz, Arabic palaeography. A collection of Arabic texts from first century of the Hidjra till the year 100o, Cairo, 1905, pl. 19-30.

8 E. Whelan, op. cit., p. 131, n. 63.

9 On many folios, a Tre lune paper with the name NPOLERO or NPOCERO has been used (see f. 3/ii). It corresponds probably to the eighteenth century restoration (see below). The original parchment, in the shape of small stripes, has been reused as a reinforcement. In at least one case (f. 2/ii), a larger piece of parchment completes the lower part of a damaged folio.

10 The number of folios kept in the Chester Beatty Library is not clear. According to Arberry's catalogue (A.J. Arberry, The Koran illuminated. A handlist of the Korans in the Chester Beatty Library, Dublin, 1967, p. 4, no 3a), the manuscript contains 201 folios. When I saw it, two groups of folios were kept separately: seventy-eight folios, numbered continuously from " 1 " to " 78 " and corresponding probably to the "better series" seen by Whelan (op. cit., p. 132, n. 70), are bound together. The rest of the folios start with "1" and the last one bears no "201". However, a few folio numbers in this second group are duplicated (f. 93, 101 and 106), but some are also missing. The latter may correspond to folios which were selected for the first group. Anyhow, they are not in the correct order as indicated by Whelan (ibid.). With the confused situation currently prevailing, I shall hereafter call the first group of bound folios Is $1404 \mathrm{i}$ and the rest Is 1404ii, although there is of course only one manuscript, but with some folio numbers used twice. In the following text, the folios will be followed by i or ii in order to identify their current position, e.g. f. $27 /$ ii means f. 27 of Is 1404ii.

11 See E. Whelan, op. cit., p. 119. The note also relates the restoration of the volume in $1140 / 1727$. 
manuscript to have consisted of about 410 folios. In other words, ca. 78 square meters were needed for the production of this copy.

Most of the folios are now isolated, but a few bifolia have survived, for instance f. 18-19/ii, and, more interestingly, f. 46-51/ii and 56-63/ii (with f. 59/ii and $60 /$ ii missing). ${ }^{12}$ Their dimensions indicate clearly that the manuscript was a folio volume. In the two places with textual continuity on a few folios (f. $46-$ $5^{1 / i i}$ and $56-63 /$ ii), it is possible to note that the sequence of the parchment sides does not conform to the situation usually found in Islamic manuscripts: the hair sides face hair sides and conversely the flesh sides face flesh sides. ${ }^{13}$ Unfortunately, the state of the material does not allow to identify the quires which constituted the manuscript, but they were at least ternions.

As noted by Whelan, the script is of the same thick variety as that found on the Sanaa folios. The alif ends in a lower return almost flat on the line. Final or isolated $q \bar{a} f$ is recognisable by its sickle-shaped tail. Final or isolated mim looks like a breve with a triangular tail to the left. The body of final nūn is vertical; the upper part of the letter is a curve and the lower is a comparatively short one. The lām-alif is almost symmetrical, with its two branches curving towards the other one. The diacritics are thin strokes, not very numerous. The $q \bar{a} f$ is indicated by a stroke over the head of the letter and $f \bar{a}^{\prime}$ by a stroke below it. The copyist(s) used short line-end fillers, frequently curved. The short vowels are noted with red dots.

The orthography awaits a more thorough study. However, a brief survey shows that the scriptio plena is now common for qāla and that shay' is written without alif. The long $\mid \bar{a} /$, indicated by an alif, is integrated into the rasm, in some cases more extensively than in the King Fu'ad edition. As for bi-āyāt, it has been written with three denticles_-for instance on f. 57a/ii, in 3: 4 . In the same place, $d h \bar{u}$ is also written in the old orthography, with an alif. In contrast with Inv. 20-33.1, 'alà is written with an alifmaqșūra. Although there is no study of the orthography of third/ninth century Qur'anic manuscripts, a quick survey of the material suggests that these orthographic peculiarities had altogether disappeared in that period. Red dots mark the short vowels, but it is not clear whether this is original or a later addition.

The manuscript was not divided into $j u z^{\prime}$ as the text is continuous on folios where one of these divisions would have implied either the beginning or the end of a section. ${ }^{14}$ A set of seven volumes is excluded for the same reason. It was

\footnotetext{
12 Whelan only indicates f. $56-57$ and $65^{-66}$ (ibid.).

13 Also noted by Whelan on the basis of sequences of continuous text (ibid.).

14 Whelan, op. cit., p. 120.
} 
either a single volume - and this seems the most probable — or a two-volume mushaf (the middle of the text has not been preserved).

The verses and groups of verse divisions are hardly decorative: the former are marked by three or more diagonal dashes, and the circles singling out the groups of ten verses seem a later addition. The basmala is considered as a verse. Illumination is restricted to sura headbands. Thirty-four of them have been preserved. ${ }^{15}$ They do not include any indication about the suras - their titles or number of verses have been added later in red in the margin. They have most of the time a rectangular shape, defined by a rope motif in more than half of the cases. ${ }^{16}$ In some instances, they adjust to the space available and fill out the end of the last line of the preceding sura when some blank space has been left (e.g. sura 3 , f. $56 \mathrm{~b} / \mathrm{ii}) \cdot{ }^{17}$ In a few places, when the last word was alone on the last line, it has been covered by an illumination (see for example sura 36 , f. $59 \mathrm{a} / \mathrm{i}$, or 37 , f. 63a/i). On both extremities, a vignette of vegetal inspiration, with sinuous twigs bearing leaves, extends into the margin. Some of them are different: their composition is of a simpler nature, probably the work of another illuminator (see for instance sura 7 on f. $26 \mathrm{a} / \mathrm{i}$ or 15 on $\mathrm{f}$. $36 \mathrm{a} / \mathrm{i}$ ). Very often, those in the outer margin have been lost. Blue, yellow, red and green have been used, but in a few cases there seem to be traces of gold, e.g. on the ornaments of sura 38 (f. 13a/ii) or 77 (f. 194b/ii). As noted previously, they may have been added at a later stage. A dry point ruling for the headbands is visible in some places.

The ornamentation relies heavily on heart-shaped palmettes (or half-palmettes), sometimes expanded into an almost diamond shape in order to get a symmetrical disposition. They are sometimes alone (sura 36, 37, 42, 69, 8o, 81), sometimes combined with geometrical shapes like diamonds (sura 4, 41), circles (sura 5, 12, 40) and half circles (sura 35 [fig. 36] and 67). In all cases, natural components are integrated into the composition. They are also present when

15 S. $3-9,12,13,15,16,20,33-38,40-42,62,67-70,77-83$; in two cases, the illumination is covered by a paper restoration (f. $2 \mathrm{~b} / \mathrm{ii}$ and f. $78 \mathrm{~b} / \mathrm{ii}$; the former could not be identified and the latter is that of s. 8). Moritz reproduced the headbands of sura 3 (f. $56 \mathrm{~b} / \mathrm{ii}$; B. Moritz, op. cit., pl. 19), 4 (f. 51a/ii; B. Moritz, op. cit., pl. 20), 12 (f. 123a/ii; B. Moritz, op. cit., pl. 21), 15 (f. 36a/i; B. Moritz, op. cit., pl. 22), 34 (f. 57 b/i; B. Moritz, op. cit., pl. 23), 35 (f. 70a/i; B. Moritz, op. cit., pl. 24), 67 (f. 191a/ii; B. Moritz, op. cit., pl. 25), 70 (f. 193a/ii; B. Moritz, op. cit., pl. 26), 77 (f. 194b/ii; B. Moritz, op. cit., pl. 27), 79 (f. 75b/i; B. Moritz, op. cit., pl. 28), 80 (f. 77a/i; B. Moritz, op. cit., pl. 29) and 81 (f. 78a/i; B. Moritz, op. cit., pl. 30).

$16 \operatorname{Suras}_{3}$ (B. Moritz, op. cit., pl. 19), 5-7, 9, 15-16 (B. Moritz, op. cit., pl. 22), 20, 33, 38, 62, 67 (B. Moritz, op. cit., pl. 25), 77-79 (B. Moritz, op. cit., pl. 27 and 28) and 82 have either no frame or another kind of frame.

B. Moritz, op. cit., pl. 19. 
geometrical shapes structure the headbands (see for instance sura 9, 13, 34, 79). The rosettes which occupy the centre of the circles in the illumination before sura 9 are related to those found in the decoration of Qașr al-Hayr al-Gharbīi ${ }^{18}$ or those before suras 41 or 54 in the Damascus codex. The inspiration of a few illuminations is clearly different. On the whole breadth of the headband on f. $26 \mathrm{a} / \mathrm{i}$, diamonds are traced by two interlacing zigzags, each of them interlacing with four independent but tangent ovoid shapes (surah 7 ). Sura 20 is preceded by a white interlace within a frame with a rope reserved on a green background, a small square highlighting its corners (f. $46 \mathrm{~b} / \mathrm{i}$ ). A more complicated interlace, organised around alternating four and eight-pointed stars, separates sura 15 from the next one (f. 36a/i). A headband with a scroll bearing leaves and grapes has been preserved before the beginning of sura 77 (f. 194b/ii; fig. 37). ${ }^{19}$ In most of the compositions, the outline of the palmettes, of the geometrical shapes or of the scroll looks very slender.

Is 1404 puzzled scholars: Moritz dated it to the second-third/eighth-ninth centuries, Josef von Karabacek opted for the third/ninth century in a critical review of Moritz' Album, ${ }^{20}$ Arthur Arberry avoided taking position on this issue in his catalogue of the Qur'anic manuscripts in the Chester Beatty Library, ${ }^{21}$ and David James, in the catalogue of an exhibition, dated it to the fourth/tenth century. ${ }^{22}$ Whelan's suggestion has already been mentioned above.

The question of the date should not be separated from that of Sanaa, DaM Inv. 20-33.1. There is an obvious relationship between the script of the latter (which I suggested to call the "Umayyad codex of Sanaa"23) and that of the Dublin manuscript. Unfortunately, little remains of this copy, which had originally 520 folios according to Von Bothmer. ${ }^{24}$ From his publication, one

18 D. Schlumberger, Qasr el-Heir el Gharbi, Contributions de M. Ecochard et N. Saliby, Mise au point par $\mathrm{O}$. Ecochard et $\mathrm{A}$. Schlumberger [Bibliothèque archéologique et historique, CXX], Paris, 1986, pl. 33 (centre left) and 34 (frame).

19 B. Moritz, op. cit., pl. 27. See also s. 82 (f. $78 \mathrm{~b} / \mathrm{i}$ ).

20 J. von Karabacek, Arabic palaeography, WZKM 20 (1906), p. 136.

21 A.J. Arberry, op. cit., p. 4, no za.

22 D. James, Qur'ans and bindings from the Chester Beatty Library, London, 1980, p. 23, no 10.

23 F. Déroche, New evidence about Umayyad book hands, in Essays in honour of Șalāh al-Dīn al-Munajjid [al-Furqān publication, $\mathrm{n}^{\mathrm{o}}$ 70], London, 2002, p. 629. Behnam Sadeghi's decision to call the Sanaa palimpsest, DaM Inv. 01-27.1, Codex Șan' 'à' I complicates things as the two names are too close to avoid confusion (see ch. 2 and B. Sadeghi and U. Bergmann, The Codex of a Companion of the Prophet and the Qur'an of the Prophet, Arabica 57 [2010], p. 347).

24 H.-C. von Bothmer, op. cit., p. 5. Twenty-five folios have been found so far. 
understands that only loose leaves have been preserved, the largest one measuring $44 \times 36,5 \mathrm{~cm}$. However, he contended that the original dimensions of the volume were $51 \times 47 \mathrm{~cm} .{ }^{25}$ As in the Dublin manuscript, a standard page of text contains 20 lines. Von Bothmer came to the conclusion that the manuscript was made originally of single sheets: ${ }^{26}$ in other words an entire sheet of parchment has been used for each folio. ${ }^{27} \mathrm{He}$ argued that the size of the folios in itself precludes that they could have been the half of a bifolio and that the disposition of the parchment sides, with hair sides facing hair sides and, conversely, flesh sides facing flesh sides, could only be the result of the possibility the copyist(s) had to arrange the sequence according to their own purpose. ${ }^{28}$ The usual sequence (flesh facing hair except in the centre of the quires and when facing the contiguous quire) would conversely imply the use of bifolios.

These arguments fail to convince. The dominant parchment quire found in later copies of the Qur'an (quinions with flesh sides facing hair sides) was one of the possibilities during the first century of Islam, not the only one. Quires prepared according to Gregory's rule, i.e. with the same sequence as that described by Von Bothmer, are already found in the Codex Parisino-petropolitanus and had some diffusion in the earliest times. Dublin, CBL Is 1404 is itself constituted of quires relying on this sequence. On the other hand, the reasons for the author's upper estimate of the size of the folios are not explained. Even if we admit that they were larger than in their current state, their size does not exclude that they would have been the half of a bifolio. Actually, the Dublin manuscript was prepared with bifolios measuring perhaps slightly more than $47 \times 76 \mathrm{~cm}$ and I shall analyse below another copy of the Qur'an with bifolios measuring $50 \times 86 \mathrm{~cm}$, very close to the dimensions of Von Bothmer's reconstruction of the original size of the manuscript $\left(5^{1 \times 94} \mathrm{~cm}\right)$. In other words, as Is 1404 , Inv. 20-33.1 is a folio muṣ haf.

If the estimate of $5^{20}$ folios for the manuscript in its original state is correct, it means that 260 hides of animals were needed in order to produce this Quran. According to an approximation based on a page of text, I would rather suggest a number of ca. 370 folios. In other words, about 90 square meters of parchment were needed; less than the 124 square meters implied by Von Bothmer's hypothesis, but still a herd of 185 animals.

\footnotetext{
25 Ibid.

26 See F. Déroche et al., Islamic codicology, an introduction to the study of manuscripts in Arabic script, London, 2005, p. 14.

27 Ibid., p. 16.

28 Ibid., n. 139. See the description of the dominant parchment quire in F. Déroche et al., op. cit., pp. $74-76$.
} 
The isolated alif ends with a lower return toward the right in the shape of an open hook, more marked than in Is 1404. The shaft is upright and terminates in a bevel. The shape of medial 'ayn/ghayn, with its right antenna vertical and the left one slanting to the left, does not differ from that seen previously. As in the majority of the manuscripts of the Umayyad period, ${ }^{29}$ the lower horizontal stroke of final $k \bar{a} f$ extends to the left, although in an apparently more subdued way than in the Fustat codex, for instance. Final mim looks like a semibreve with a tapering triangular tail to the left, much thinner than in the previous manuscript. The inverted L-shaped final nūn exhibits a fat shaft with its upper part slightly bent to the left; the short perpendicular lower return is slightly thinner and longer than in Is 1404. The two branches of the lām-alif arise from an asymmetric triangular basis and curve slightly towards the vertical axis of the letter. When situated at the beginning of a word or within it, the $h \bar{a}^{\prime}$ is triangular, with its two "eyes" looking like a chevron. The scribe uses sometimes line-end fillers, usually short ones.

The diacritical marks are rather numerous; $f \bar{a}$ is recognisable by the stroke above the letter, $q \bar{a} f$ being conversely identified by a stroke below it. Red dots indicate the short vowels, according to the system attributed to Abū 'l-Aswad al-Du'ali. The question of the date of their introduction has been discussed in the previous chapter: although there is no conclusive evidence in support of their use by the end of the first/seventh or beginning of the second/eighth century, the multiplication of muṣhafs with red dots indicating the short vowels points to the fact that their diffusion had started by then.

The analysis of the orthography which I can offer here will remain tentative, as it relies on the few pictures of the manuscript which have been published so far. From what I could gather, the scriptio plena seems to have made advances similar to those found in Is 1404 when compared with the previously examined copies. 'Adhāb and 'ibādì are both written with an alif, that is to say in conformity with the scriptio plena. The old orthography of $\bar{a} y \bar{a} t$, when introduced by $b i$-, is still present, with its three denticles. A new feature is the transformation of 'alā: in place of the alif maqșūra, it is written with an alif mamdūda. If we compare $\mathrm{f}$. 69 of the Codex Parisino-petropolitanus with a folio of the Sanaa manuscript, it becomes clear that the $f \bar{a}$ il forms are now written with an alif after the first consonant. Some of the plurals remain nevertheless in scriptio defectiva, as $a^{c} j(\bar{a}) z$, next to others in scriptio plena.

29 F. Déroche, Un critère de datation des écritures coraniques anciennes: le kăffinal ou isolé, Damaszener Mitteilungen 11 (1999), pp. 87-94 and pl. 15-16 [In memoriam M. Meinecke]. 
The verses are marked by thin diagonal strokes; the groups of five and ten verses have been highlighted at a later date. The basmala is indicated as a verse.

The outstanding initial double page with illumination is certainly the bestknown feature of the manuscript - but I should also add that it is to my knowledge one of the first copies of the Quran, if not the first one, of which both the beginning with sura al-Fātiha (sura 1) and the end with sura al-Nās (sura 114) have been preserved. For the history of the text in the context of John Wansbrough's hypothesis, the manuscript is an important witness at the beginning of the second/eighth century. In its present state, it opens with a large eightpointed star on the first recto. ${ }^{30}$ Was it so from the beginning or did a first folio disappear which had, facing the illumination of today's f. 1 a, another eightpointed star? It is impossible to decide. On the outside of the star, trees surge from the corners located between the points of the star, their trunks passing successively over and under the frames of the star. They grow from a central circle with interlace decoration.

The first - and certainly the most famous - preserved opening is the next one (f. $1 \mathrm{~b}$ and 2a) with its representation of two buildings which have been interpreted as two mosques. ${ }^{31} \mathrm{On} \mathrm{f}$. $\mathrm{b}$, a building with a row of arcades is depicted. In its lower part, two doors which can be accessed by a flight of stairs are still visible. Next to the central stairs stands a vase. Only half of the "inner" part of the building is displayed, but this is enough to understand that there is a central nave, with arches which are higher and larger than the side arcades - two of the latter are equivalent to one central arch. There are lamps hanging in the arcades. In the upper part of the central nave, one sees a ramp. On top of the enigmatic building, trees are growing. ${ }^{32}$ The frame, a band of floral interlace, is in a somewhat different spirit from the rest of the very factual representation - with the detail of a staircase in the damaged upper part of the vertical frame. Facing this full-page picture, another building has been depicted in the same realistic manner, but with a completely different organisation (f. 2a). The arcades with lamps hanging from

30 H.-C. von Bothmer, op. cit., pp. 12-13, fig. 9; already in H.-C. von Bothmer, Frühislamische Koran-Illuminationen: Meisterwerke aus dem Handschriftenfund der Großen Moschee in Sanaa/Yemen, Kunst und Antiquitäten (1986/1), fig. 1. Compare with D. Schlumberger, op. cit., pl. 73 .

31 H.-C. von Bothmer, op. cit. (1987), pp. 5-8, pl. I-II and figs. 1, 2, 5 and 7.

32 Compare with M. Bernabo et al., Il Tetravangelo di Rabbula: Firenze, Biblioteca medicea laurenziana Plut. 1.56. L'illustrazione del Nuovo Testamento nella Siria del VI secolo, Rome, 2008, pl. VI-X, XVI, XVIII-XXIV. 
them surround a courtyard. A larger arch is located in the upper part, between the trees which, as in the former instance, are depicted "on top" of the building.

On f. 2 b, the beginning of the text (s. 1 and the first verses of s. 2 ) is written within a double frame, the first one in a series of increasingly lighter frames on the following openings (i.e. what can be seen when the manuscript is open). ${ }^{33}$ The last one is constituted by a band decorated with palmettes and circles and marked at its corners by a square with a motif in the shape of an $\mathrm{X}$. As a consequence, the number of lines within the frame becomes more important. After this first sequence, the text seems to have been transcribed normally, although there is no evidence to show us what the central part of the manuscript looked like. At the end of the volume, starting with sura 96 , the text appears again within frames, those of the last three openings being especially broad. A fragment with sura 114 has been preserved: the text is written within a frame decorated with tendrils and leaves. From what has been preserved from the end of this luxurious copy, it appears that it was partly constructed on a symmetry in the presentation of the first and last openings of the manuscript.

The sura headbands are an important component of the illumination of the manuscript. They originally did not contain any indication of title or number of verses - this information has been added later, in gold, over the original illuminations. ${ }^{34}$ They do not always have a strictly rectangular shape but sometimes fit the space available on the last line of the preceding sura. In other words, they fill out the end of the last line of the preceding sura when it is not totally occupied by the text. When this happens, the headband may be partly reduced on its right side: it then takes the shape of a thinner band from which various vegetal elements grow, or that of a stylised vegetal twig. ${ }^{35}$ As in Is 1404, a vignette is usually found at both extremities of the headband, but sometimes there is only one on the left side. ${ }^{36}$ This seems to happen often when the left part of the headband is a twig. It should be noted that the vignettes only encroach slightly on the margins. As a rule, the extremities of the headband proper are always located within the written surface and not on the vertical line which defines the justification. These illuminations rely on a variety of ornamental sources: vegetal, braided, geometrical ... A similar variety can also be observed in the

\footnotetext{
33 H.-C. von Bothmer, op. cit., p. 13 and fig. 10.

34 Ibid., p. 5 and 13 .

35 Ibid., p. 13 and fig. 23.

36 Ibid., p. 13.
} 
shape of the vignettes-e.g. half palmettes, pair of wings. An arrow surrounded by a scroll adorns the space left blank at the end of sura 55, according to Von Bothmer. ${ }^{37}$

The date of the copy has been a subject of discussion. In the exhibition catalogue Mașa hif Șan ' $\bar{a}$, it was referred to as "the Umayyad mușhaf" and dated to the beginning of the second/eighth century. ${ }^{38}$ Von Bothmer suggested that the copy was completed by the end of al-Walìd's reign, between 710 and $715 \cdot{ }^{39} \mathrm{~A} \mathrm{C14}$ dating of the parchment of this manuscript was performed and the calibrated results of the measurements concluded that it had been produced between 657 and $690 .{ }^{40}$ However, Von Bothmer stuck to his date. Both he and Jenkins agreed in considering that the manuscript was produced in Syria. ${ }^{41}$ Against this Umayyad attribution, Whelan wrote that she "hope[d] to demonstrate [that] there are parallels suggesting a date later than the Umayyad period", although she never published the article which was supposed to challenge Von Bothmer's conclusions ${ }^{42}$ We only know of her views in relation to what she said when discussing the Dublin manuscript, CBL Is 1404.

The parallels which can be established between Inv. $20-33.1$ and Is 1404 point to their contemporaneity. Their dimensions, in their present state, are very close $(44 \times 36,5$ against $47 \times 38 \mathrm{~cm})$. A codicological examination of the manuscript showed striking similarities between the two copies: both are folio manuscripts, with parchment quires relying on a sequence of the hair and flesh sides in accordance with Gregory's rule. The script of both Inv. 20-33.1 and Is 1404 is considerably thicker than that of the Umayyad codex of Fustat, for instance. It shares with it a tendency to accentuate the width of the letters, but relies for its execution on a tool with a larger tip which was to some extent adapted to the folio copies of the Qur'an so that the script would not only be fully adapted to a larger page, but would also allow the production of balanced three-dimensional volumes. The thickness of the stroke means that a technical evolution had taken place. It was not only a matter of cutting a thicker nib;

37 Ibid. Unfortunately, the author did not reproduce this detail.

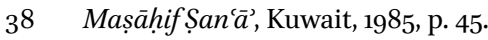

39 H.-C. von Bothmer, op. cit. (1987), p. 16.

40 Hans-Caspar von Bothmer, Karl-H. Ohlig and Gerd-R. Puin, Neue Wege der Koranforschung, Magazin Forschung, Universität des Saarlandes 1 (1999), pp. 33-46. A. George mentions an unpublished dating of the ink which suggested a date between 700 and 730 (The rise of Islamic calligraphy, London, 2010, p. 79).

41 H.-C. von Bothmer, op. cit. (1987), p. 16; M. Jenkins, op. cit., p. 23.

42 E. Whelan, op. cit., p. 125. 
it probably involved a change of tool or of material as well as a change in the movements and position of the copyist. This evolution is all the more striking in that it seems somewhat sudden and no comparable tool seems to have been known in other manuscript traditions of this area. The decision to write 20 lines to the page is certainly more than a mere coincidence. In both cases, the scriptio plena is now prevalent, but some early features are still present, for

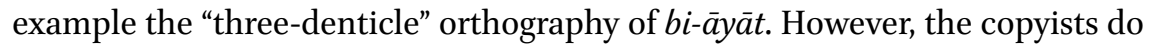
not share the same opinion about 'alä: Is 1404 keeps to the "old" orthography (which is actually still valid today) with the alifmaqșüra, and Inv. 20-33.1 uses a "reformed" orthography, with an alif mamdüda.

Although a comparison of their illuminations is necessarily restricted to the sura headings, it suggests that the artists relied on a shared repertoire. The palmettes, so ubiquitous in Is 1404 (fig. 35 and 36 ), are prominent in the headband preceding sura 85 in Inv. $20-33.1{ }^{43}$ In the latter, the association of circles and diamonds before suras 75 and $91^{44}$ recalls the headband before sura 62 (f. 188a/ii) or possibly that of 9 (f. 33 b/i) in Is 1404 . The scroll with grapes and leaves of sura 80 can be compared with the ornament following sura 67 in Inv. $20-33 \cdot 1,{ }^{45}$ and the white interlace in the headband of sura 20 (f. $46 \mathrm{~b} / \mathrm{i}$ ) is inspired by the same model as the two components of the frame for sura 114 in the Sanaa codex.

Parallels with earlier or contemporary manuscript traditions and works of art have been offered ${ }^{46}$ At the most general level, the influence of earlier large-size copies of the Bible probably played a role in the evolution, which resulted in an increased size for copies of the Qur'an. ${ }^{47}$ In Inv. 20-33.1, the illumination on $\mathrm{f}$. 1a has been paralleled to the famous dedicatory picture at the beginning of Vienna's Dioscorides, a manuscript of the sixth century, with the portrait of the patron of that copy, Julia Anicina. She is depicted within an eight-pointed star which is found in the same position as the figure in Inv. 20-33.1. Architecture was part of the repertory used in religious Christian manuscripts. The first and most common instances are the canon tables which appear traditionally as lists framed by columns and crowned by arcs. In the case of the Rabbula Gospels, a copy completed in 586 in Northern Syria, paintings

\footnotetext{
43 H.-C. von Bothmer, op. cit. (1987), fig. 15.

44 Ibid., fig. 14 and 17.

45 Ibid., fig. 20.

46 H.-C. von Bothmer (ibid., p. 14 and 16) repeatedly underscored the links with the Late Antiquity.

47 Th.S. Pattie, The creation of the great codices, in J.L. Sharpe III and K. Van Kampen eds., The Bible as book, The manuscript tradition, London, 1998, pp. 61-72.
} 
also use an architectural component as a setting for the representation of the figures, either isolated or in groups. ${ }^{48}$ In the Late Antique painting tradition, the architecture provides a particular solemnity to the scene. ${ }^{49}$ It may also be seen as an ideal image of the religious building, a visual allusion which could have seemed especially meaningful to the patrons of the manuscript of Sanaa. ${ }^{50}$ The diffusion of this iconography had, probably before the seventh century, reached regions as remote as Ethiopia, as shown by the Abba Gärima Gospels. ${ }^{51}$ In Umayyad times, the mosaics of the Great mosque in Damascus indicate that this iconography was still in use in an Islamic context and both the Fustat and Damascus codices confirm its presence in the repertoire of Quranic manuscript illumination. The date of the fragment Sanaa, DaM Inv. 20-33.1 can be established on the basis of these parallels, as well as on the study of the techniques used for its production and of its orthography. The $\mathrm{C}_{4} 4$ results are indicative of a chronological position excluding any attribution to a considerably later period.

Both the Sanaa copy and the Dublin manuscript CBL Is 1404 were produced during the first decades of the eighth century, under Umayyad rule and probably in some official context. The cost of these copies has risen dramatically when compared with former mușhafs like the Fustat codex. The reflection on the appearance of the sacred book had been applied to both the general outer appearance (the muṣhaf must be a large book) and to the presentation of the text (the muṣhaf must be a beautiful book). A genuine culture of the book had developed-at least in some milieux.

Both manuscripts were far from being isolated instances of large-size Quranic copies and more evidence about the production of folio muṣhafs is available. Although they do not provide information about more common manuscripts, they illustrate an aspect of Quranic manuscript production during the last decades of Umayyad rule.

Before turning to three other instances related to Is 1404 and Inv. 20-33.1, a manuscript palaeographically closely related to both copies should be men-

48 See C. Ceccheli, G. Furlani and M. Salmi, The Rabbula Gospels, Olton, 1959, pl. 1a, 2a, 9b and 14a; M. Bernabo et al., op. cit., pp. 84-86, pl. I-III and XXVII.

49 See for instance in Umayyad times, D. Schlumberger, op. cit., pl. 34, upper level and 68, d and e.

5o A. George, op. cit., pp. $85^{-86}$.

51 J. Mercier, La peinture éthiopienne à l'époque axoumite et au XVIII ${ }^{\mathrm{e}}$ siècle, Comptes rendus de l'Académie des inscriptions et belles-lettres 2000, pp. 36-45 et fig. 1-2. See in n. 1 the references to the first publications about these paintings by J. Leroy. 
tioned here. ${ }^{52}$ Its script is very similar and its appearance indicates that it is a large volume (fig. 38 ). However, the number of lines to the page (18 lines) is different and it apparently contains no sura illumination. There is no trace of short vowel marks on the picture published.

Returning to the group of 2o-lines-to-the-page copies, another item among the fragments from Sanaa can be added to the list (fig. 39). It has been exhibited in Kuwait in $1985^{53}$ and more recently in Amsterdam. ${ }^{54}$ Although it was never properly published, I could quickly examine some of the folios in Sanaa and recently complemented the information I had gathered with additional data. ${ }^{55}$ Some twelve parchment folios are kept in the Sanaa collection under the call number Inv. $01-29 \cdot 2 .{ }^{56}$ The largest folio in its current state is $40,5 \times 38,5 \mathrm{~cm}$. There are 20 or 21 lines to the page and the height of the written surface

52 I only know the manuscript, containing 332 folios with paper replacements, through the pictures published by B. Moritz (op. cit., pl. 17-18); according to A. Grohmann, the call number of the manuscript in Dar al-Kutub is Mașāhif 387 (The problem of dating early Qurāns, Der Islam 33 [1958], p. 216, n. 17). A few leaves probably from the same copy have been offered for sale in Paris a few years ago (Boisgirard, expert A.M. Kevorkian, Hôtel Drouot, 28 and 29 April 1997, lot no 38). The date of the waqf has been subject to debate: Moritz read 168/784-785, but J. von Karabacek opted for 268/881-882 (op. cit., p. 136), followed by D.S. Rice (The unique Ibn al-Bawwāb in the Chester Beatty Library, Dublin, 1955, p. 2, n. 4) while the author of the description in the Cairo library catalogue preferred 368/978-979 (Fihrist al-kutub al-'arabiyya al-mawjūda bi-l-kitābkhāna al-khidīwiyya, Cairo, vol. 1, 1310/1893, p. 2, no 17852; also E. Whelan, op. cit., p. 133, n. 85). As pointed out by Rice, the waqfiyyah is referring to "al-jāmi 'al-'atīq" of Fustat, which excludes Moritz' reading since the mosque could only be defined al "old" after the completion of the mosque of Ibn Ṭūlūn in 265/879.

53 Mașāhif Șan' $\bar{a}^{\prime}$, op. cit., p. $48, \mathrm{n}^{\circ} 35$.

54 Earthly beauty, heavenly art. Art of Islam, M.B. Piotrovsky and J. Vrieze eds., Amsterdam, 200o, p. 195 and figs. on pp. 214-215. Also in H.-C. von Bothmer, op. cit. (1986/1), p. 27 and fig. 3 .

55 This fragment and a second one which will be discussed below were analysed by H.-C. von Bothmer in a paper read during the Les origines du Coran, le Coran des origins conference in Paris (March 2011).

56 The fragment was exhibited in Kuwait under the call number 20-29.1 (Mașāhif Șan'âa, p. 48, no 35). In the call numbers devised for this collection, the first number indicates the number of lines (and "oo" a varying number of lines to the page) and the second one corresponds to the largest width of the writing surface of the manuscript. H.-C. von Bothmer discovered that some folios had 21 lines of script to the page and changed accordingly the call number to Inv. 01-29.2 (communication during the conference 'Les origines du Coran, le Coran des origines', Paris, 3-4 March 2011). 
varies slightly between 30,8 and $32 \mathrm{~cm}$, its width being ca. $29 \mathrm{~cm}$. The verses are separated by clusters of strokes. The groups of five verses are indicated by a circle with the letter $h \vec{a}$ in reserve on a red ground, those of ten by a combination of a circle with a four-pointed star; a letter with its abjad value is written in the centre of this ornament, thus specifying the number of verses. One of the peculiarities of the verse division of the fragment is found in sura 16. The canonical verse 16: 91 is divided into two parts after kafilan. From a typological point of view, the situation recalls strongly the "short verses" of the Codex Parisino-petropolitanus which seem to have been providing a rhyme to a textual element which was not in consonance with the adjoining ones. ${ }^{57}$

The transcription which was probably entrusted to two copyists ${ }^{58}$ was executed in a script which strongly recalls that of the two previous mushafs. However, its seems somewhat more "relaxed" than in the two previous examples. The shaft of the alif tends to be slightly rounded and the final nūn ends with a shorter lower return. The mim is circular and the lower part of its body is visible below the base line. The läm-alif has a somewhat simpler X shape. The diacritical marks, in the shape of thin diagonal strokes, are rather numerous; the $f \bar{a}^{\prime}$ can be recognised by a stroke above its head, $q \bar{a} f$ being indicated by a stroke below the letter. The short vowels are not marked on the few folios which have been preserved.

With little material at hand, it is difficult to assess the state of the orthography of this manuscript. It apparently verges towards the scriptio plena, with $|\bar{a}|$ frequently indicated. Shay' appears with its "modern" orthography (17:12), but bi-äyātina (11: 96) has kept the "three denticles" of the older tradition.

The most striking feature of these folios is the decorated frame which surrounds the text (ca. $36 \times 31,8 \mathrm{~cm}$ on the outside). It always consists of coloured bands on which runs a torsade, reserved on the ground, with loops of varying length. In one case, short oblique segments replace the torsade. The corners of the frame are marked out by a square in a colour contrasting with that of the longer segments - not unlike those of the last frame of the initial sequence in Inv. 20-33.1, with a smaller square inserted in it-or of the headband of sura 20 in Is 1404 (f. $46 \mathrm{~b} / \mathrm{i}$ ).

Our information about the illumination is restricted to the two sura headbands which have been preserved, that is to say those between sura 9 and 10 on the one hand and sura 14 and 15 on the other. The compositions are purely decorative and there is no indication of the name or number of verses of the

57 See ch. 1.

$5^{8}$ H.-C. von Bothmer's communication (see above). 
sura. The first example shows an undulated twig with red pomegranates in the loops and yellow lanceolate leaves set in the triangles between the twig itself and the sides of the frame. In the space left blank at the end of the last line of sura 9, the illuminator has painted a very stylised green twig. The composition is not unlike that found on Inv. $20-33.1$ on the bottom of the page with the end of sura 67 . The other sura headband also draws its inspiration from the vegetal world. As in the preceding manuscripts, it occupies as much as possible of the space left between the two suras. On the left side, in a red rectangle, a twig with convoluted loops bears stylised fruits and leaves. On the right, the rectangle is connected to the frame by a line on which fruits and leaves are placed in alternating sequence. The repertory is very close to some of the material in Inv. 20-33.1, but it has been executed with less skill. Von Bothmer suggests a Yemeni provenance for this copy. 59

Another Qur'anic manuscript from Sanaa, DaM Inv. 20-31.1, should be mentioned here. It is a copy in vertical format, with 20 lines to the page. In terms of its size, it is closer to the Umayyad codex of Sanaa ${ }^{60}$ In this case again, the decorative repertory is close to that of the two manuscripts, Sanaa, DaM 20-33.1 and 01-29.2. Only a few folios were found with the rest of the Sanaa trove, but Von Bothmer was able to trace about 300 folios of the manuscript, in the library of the Great mosque. Instances of end of sura fillers in the shape of arrows are said to be present in this manuscript: I shall turn to this point below.

Recently, folios of a Qur'anic manuscript with 20 lines to the page set in a frame have surfaced on the market (fig. 40-43). A leaf is now kept in Copenhagen, ${ }^{61}$ another one is in an American private collection ${ }^{62}$ and several in Doha. ${ }^{63}$ The rest of the manuscript is kept in Kairouan ( $\left.\mathrm{R}_{3} 8\right)$ and the evidence is still in the process of publication. ${ }^{64}$ Nevertheless, some details are already

59 H.-C. von Bothmer's communication (see above).

6o H.-C. von Bothmer's communication (see above). As noted before, the second number (in this case 31) in the call number corresponds to the largest width of the writing surface of the manuscript. Here, it is therefore $31 \mathrm{~cm}$.

61 David collection, Inv. 26/2003. See S. Blair et J. Bloom, Cosmophilia: Islamic art from the David Collection, Chesnut Hill, MA, 2007, p. 98, $\mathrm{n}^{\circ} 33$.

62 See D. Roxburgh, Writing the word of God. Calligraphy and the Qur'ân, Houston, 2007, p. 16, fig. 5 .

63 Doha, Museum of Islamic art, MS 213; Doha, Museum of Modern Art, no 224.

64 Kairouan, Musée des arts islamiques, R 38. 210 folios are preserved in Kairouan. See M. al-Nayyal, Al-maktaba al-äthariyya bi-l-Qayrawān. 'Ard-Dalïl, Tunis, 1963, fig. 3 (the 
available. It has been written on parchment folios in vertical format measuring almost $50 \times 43 \mathrm{~cm}$ (writing surface: $35,8 \times 32,5 \mathrm{~cm}$ ). On the basis of the material published, we can estimate that roughly 80 square meters of parchment were needed for the production of this impressive muṣaf. As many of the places where the text could have been divided into volumes-like the juz' or the seventh-are present on the folios of the manuscript, we can conclude that it was probably a single volume copy. The manuscript is also important because it is, with Inv. 20-33.1, one of the first cases where both the first and last folios of a copy of the Qur'an are preserved.

The script is distinct from that of Inv. 20-33.1 or of the manuscripts which can be related to the latter. At first sight, it is more slender than the script of the previous manuscripts. The alif is upright, with the lower return in the shape of a hook more accentuated than in the previous manuscripts. The two antennas of medial 'ayn are in a similar position. Final kāf usually has its two horizontal strokes of the same length. Final mim is more rounded than in Inv. 20-33.1, but without encroaching onto the lower part of the baseline. Final nün is close to the shape this letter exhibits in C I, for instance. ${ }^{65}$ Three components are clearly recognisable: above the line, the head which is slanting to the left, then the main part of the nün, also slanting to the left but moderately, then the lower return, short and horizontal. The initial or medial $h \bar{a}$ is also more rounded on its left side. The läm-alif hesitates between an $\mathrm{X}$ shape and an asymmetrical disposition, with the right branch almost vertical, the other one curving slightly towards the vertical axis of the letter. The diacritical marks in the shape of thin diagonal strokes are rather numerous. The $f \bar{a}^{\prime}$ can be recognised by a stroke above its head, $q \bar{a} f$ being indicated by a stroke below the letter. The short vowels are indicated by red dashes, a very specific system which nevertheless follows

numbers are indicated on p. 19); Tunisie, p. 195, $\mathrm{n}^{\circ}$ 118, ill. pp. 214-215 ( $\mathrm{n}^{\circ} 118$ a à d); AlMuṣhafal-sharîfattributed to Uțthmān bin 'Affān (The copy at the Topkapı Palace Museum), T. Altıkulaç ed., Istanbul, 1428/2007, pl. 5 et 6; M. Rammah, Makhțūtāt nafisa min alturāth al-qayrawānī. Manuscrits précieux du patrimoine de Kairouan. Precious manuscripts from the Kairouan heritage, Tunis, 2009, pl. s.n.; Lumières de Kairouan, Tunis, 2009, p. 36; M. Rammah, Trésors de Kairouan. Treasures of Kairouan. Kunuz al-Qayrawān, [Tunis], 2009, pl. s.n., p. 9; Tunisie: du christianisme à l'islam. IV ${ }^{e}-X I V^{e}$ siècle, Ch. Landes and H. Ben Hassen eds., Lattes, 2001, p. 195 and pl. on pp. 214-215.

65 F. Déroche, Les manuscrits du Coran: Aux origines de la calligraphie coranique [Bibliothèque Nationale, Catalogue des manuscrits arabes, $2^{\mathrm{e}}$ partie, Manuscrits musulmans, I/1], Paris, 1983, pp. 39-40 and pl. XII-XIV; id., The Abbasid tradition, Qur'ans of the 8th to the 1oth centuries [The Nasser D. Khalili collection of Islamic art, I], London, 1992, pp. 40-41; A. George, op. cit., p. 152. 
the same rules as Abū 'l-Aswad al-Du'alì's red dots system; in the manuscript, no tanwin is indicated.

There is hardly any trace of the scriptio defectiva in the manuscript. Among the five items, which I have been using in order to define roughly the state of the orthography in the various copies of the Qur'an which have been examined, aya with its "three denticles" version (see for instance at 30: 58, 45: 25 or 62: 5 ) is apparently a unique remnant of the old orthography. The rest is written fairly coherently according to the scriptio plena. However, as a complement to this remark, it should be noted that $d h \bar{u}$ is written with a final alif (62: 4, for instance). Conversely, a new feature is consistently present in the manuscript: 'alā is written with an alifmamdūda.

The verses are marked by columns of thin diagonal strokes. The basmala is indicated as a verse. The groups of five are singled out by a red circle, while those of ten are indicated by a specific ornament combining a yellow circle and a red square with concave sides (fig. 40). In the middle of each side, there is a green dot. The circle has sometimes received a more elaborate decoration, but above all the illuminators paid attention to the ornaments for the hundreds, highlighted by their larger size.

Like Inv. 20-33.1, the copy has been conceived with a symmetry in the illumination between its beginning and its end. Although the ornamentation of the copy is far less ambitious than was the case for the Sanaa codex, it has been carefully planned. From the first folio preserved, probably the left hand half of the first opening (equivalent to f. $1 \mathrm{~b}$ and 2a), only the upper half has been preserved. The illumination which was set centrally on the opening page has unfortunately been severely damaged. It was beyond doubt circular, with an outer crown made of a series of incomplete tangent red circles, with a green outline on the interior. Towards the outside, these figures serve as a basis for a green three-pointed shape (a leaf?), the branches of which are separated by two petals. Part of a circle of pearls which separated the outer crown from the inner part of the circle is still visible. We can only speculate as to the composition which was found within the circle. Was it an eight-pointed star as in the Sanaa copy, Inv. 20-33.1?

On the verso, the text is written within a frame. The Fätiha begins directly below the upper segment of the frame, without any headband. Then a headband separates it from the sura al-Baqara. We can deduce from this that the headbands were meant as devices marking the end of the suras.

Two folios from the end of the volume have been preserved-although in poor condition. They correspond to the double page opening with the last two suras. Both suras have been transcribed in the middle of the page, in a space reduced on both sides by a vertical band of ornament. Above and 
below, an illumination covering the space available completes the frame for the text. The two facing pages are symmetrical in their distribution, but not in their ornamentation: the illumination above sura $a l-N a \bar{s}$ (114), a reticulation of octagons, is alone in its kind - the other three relying on hexagonal cells. The last word of sura al-Nās is followed by a thin twig, then by a basmala as the last line of text. The verso, the last page which has been preserved, is decorated by a square (fig. 43). A white twig bearing green leaves on a red ground runs between two lines of yellow pearls within the oblong rectangles constituting the four sides of its frame. The corners are highlighted by a square containing a quatrefoil. A circular figure is enclosed within the frame, on a background left blank. Four concentric bands decorated with heart-shaped motives, pearls and a rope, separated from each other by a coloured fillet, constitute the circumference. The inner part of the circle is occupied with an eight-pointed star on a green background. The star itself consists of two interlaced squares, in reserve. Each of its points is painted in red and the central octagon is filled by a circle, in the centre, surrounded by eight tangent circles with geometric design.

Illumination is present on all the folios of the manuscript since the text is enclosed by a frame similar to that of Sanaa, DaM Inv. 01-29.2 (fig. 39). As in the Yemeni fragment, its sides are enhanced either by oblique segments or by a rope pattern reserved on the coloured ground. The latter appears in two variants. Each of the four corners of the frames is enhanced by a square which contrasts by its colour with the rest of the frame and contains a smaller square reserved in its centre.

Illuminations are also found between the suras (fig. 40-42). The space between the latter varies from usually one to two full lines that have been left empty by the copyist(s). It also happens that, when most of the last line of a sura is blank, the copyist refrained from leaving a line empty (as is the case for sura 24, but it may also be due to the fact that there was only room for one line of text). When a sura ends on line 20, the space left after the last word received the illumination. As a rule, the space has then been filled in by headbands which are devoid of any information. They occupy the width of the justification, usually linking one inner side of the frame to the other one. When part of the last line of the preceding sura does not contain text, the illuminator usually used it for the headband which may therefore have an irregular shape-as was the case with Inv. 20-33.1. Conversely, it sometimes happened that the right part of the space was not sufficient to allow the illuminator to prolong the same ornament until the margin. In such cases, a twig connects the rectangular headband to the margin; in many instances, it supports a vegetal component-flowers or leaves. Another solution used by the illuminators was to insert either an arrow at the end of the last line of the sura when a space had been left blank, or a twig with leaves. 
The repertory of the headbands themselves relies mainly on geometry, less frequently on vegetal inspiration. The repetition of a figure (diamond, circle, quatrefoil ...), either juxtaposed and connected to the next one or interlaced with another figure, has been repeatedly used by the illuminators. In a similar way, they juxtaposed square or rectangular compartments filled with some simple composition across the breadth of the headbands. A few examples of braids reserved on the ground have been preserved. The panels found on the last text opening, with suras 113 and 114, rely on a reticulated composition based on hexagonal cells (above and below sura 113, below sura 114). Above sura 114, the intersections of the diagonally oriented red grid are occupied by small yellow squares, thus defining octagonal spaces. The vegetal repertory relies on scrolls bearing leaves, flowers or, less frequently, grapes (see at the beginning of suras 25 [fig. 42] and 42). The twig is often reserved on the ground of the headband. The quality of the illumination is variable and suggests that it has been the work of a team.

In a few cases, arrows have been used as sura-end fillers (fig. 42). They are usually depicted with the point towards the last word of the sura, in a very realistic way. Between sura 29 and 30 (fig. 41), the headband looks like a band set between two arrow-heads, the one on the left being larger than the other one. In addition, the space left at the end of sura 29 is filled with a roughly triangular elongated device, connected to the headband, to which eight arrows are fixed; two more arrows have been drawn vertically above the left arrow-head. The arrows appearing in a Qur'anic manuscript conjure up an account concerning al-Walìd II (who reigned from $125 / 743$ to $126 / 744$ ) who is said to have shot arrows at a muṣ. af ...6

A C14 dating of the parchment is now available and confirms the attribution of the manuscript to the early period. The results give the highest probability $(95.6 \%)$ for a date comprised between 648 and $691 \mathrm{AD}$ - a result which is very close to that of the large mușhaf from Sanaa, Inv. 20-33.1.67 I nevertheless suggest that the real date is somewhat later. An interesting feature common to the Kairouan manuscript and the Sanaa fragment, Inv. 01-29.2, is the lack of golden ornament. In spite of the impressive size of both copies, it is surprising that the patrons hesitated in having part of the illumination in gold-as is the case of Inv. 20-33.1, and the Damascus and Fustat codices. ${ }^{68}$ Indeed, yellow

\footnotetext{
66 Abū al-Faraj al-Iṣfahānī, K. al-Aghānī, Cairo, 1935, vol. 7, p. 49, l. 10-15.

67 KIA40647.

68 Gold seems present in a very few instances on MS Dublin, CBL Is 1404, but it is not clear whether it is original or the result of overpainting.
} 
seems to have been chosen as a substitute of this "colour". As the investment required for both copies of the Qur'an was without doubt quite substantial, the amount of gold needed for the illumination would not have made a big difference in the final cost. The absence of this component has certainly more to do with a decision of the patron than with the desire to spare money ${ }^{69}$ We know that by the middle of the second/eighth century, Mālik b. Anas condemned the use of gold in a copy of the Quran. ${ }^{70}$ The manuscripts may either reflect a general reaction against the use of gold, or a choice made by the patron(s) of both manuscripts in accordance with their final destination-e.g. a mosque. I would therefore suggest that both muṣhafs were produced by the end of the Umayyad rule, in the first half of the second/eighth century.

The features common to both R 38 and Sanaa, DaM Inv. 01-29.2 (framed text, similar inspiration in the illumination, original markers for the groups of verses, number of lines to the page) are puzzling and suggest a close relationshipalthough the limited amount of material preserved from Inv. 01-29.2 renders any conclusion about the illumination premature. As argued previously, the page setting of the Qur'anic manuscripts followed in many instances from an early date a form which was supported either by the tradition and its sanctity, or by the political power. Within the group of five manuscripts with 20 lines of text to the page, both copies are in keeping with a model. One cannot avoid thinking of the possible existence of a workshop which would have been producing Qur'anic manuscripts on a large scale or at least of some control over the production of officially commissioned copies.

Interestingly enough, the illumination of the Kairouan manuscript also finds parallels in the manuscript Dublin, CBL Is 1404. The headbands found before suras 76,77 and 79 in $\mathrm{R} 38$ are by their composition close to that preceding sura 9 in Is 1404 (f. 33b/i). This common inspiration appears again in the headbands of suras 6 and 86 in R 38 which recall respectively the sura ornaments found before suras 78 (f. $74 \mathrm{~b} / \mathrm{i}$ ) and 20 (f. $46 \mathrm{~b} / \mathrm{i}$ ) in Is 1404 . Among the scroll compositions of $\mathrm{R} 38$, two of them (before suras 73 and 78 ) call to mind the slender, almost too thin, twig characteristic of most of Is 1404 illuminations in general and of the headband before sura 77 (f. 194b/ii) in particular. In spite of

69 See the account about 'Umar II in the Fihrist (below, n. 72; the actual reasons are different).

70 See for instance A. Jahdani, Quelques opinions de Mālik (m. 179/796) sur le Coran-codex, [Actes de la conférence internationale sur les manuscrits du Coran (Bologne, 26-28 septembre 2002)] Mélanges de l'Université Saint-Joseph 59 (2006), pp. 274-276. 
the difference between the scripts of the two copies, their common decorative repertoire, also shared by Sanaa, DaM Inv. 01-29.2 strengthens the attribution to the same period.

Arabic sources hint at such state-sponsored operations. The "edition" of the Qur'an by 'Uthmān and the story of the official copies sent to the largest cities of the Empire could serve as the founding episode, if we take this account for granted. Al-Hajjāj is in his turn said to have been involved in the production of an edition of the text which would have been more legible and to have sent copies to the largest cities of the Umayyad empire when his enterprise was completed. ${ }^{71}$ The Fihrist provides an account about a calligrapher, Khālid b. Abī al-Hayyāj, who was hired by a certain Sa'd who may be identical with the Sa'd al-mașâhifi known through another source. ${ }^{72}$ The latter was in charge of overseeing scribal activities for al-Walīd. He may have been in charge of commissioning copies of the Qur'an and providing instructions about their lay out. The investment required for the copies which have been discussed was so high that it certainly required official support to be produced-the more so because from what has survived it seems that the operation was repeated many times. The hypothesis of a Damascene scriptorium producing large official copies which were sent throughout the empire seems far-fetched, but both the sources and the material suggest that presentation manuscripts were complying with officially elaborated guidelines.

The conception of the illumination between the suras deserves a remark: here again, there seems to have been an evolution which I suggest is mainly due to the role assigned to the ornament. The desire to have any vacant space filled in played obviously a significant role in the switch from illuminations contained in an either materially or theoretically defined rectangular space to those headbands which were adapted to the space available. A look at other contemporary manuscripts, devoid of any illumination, shows a few cases where the end of the last line of the sura supports the idea that the need to prevent any addition or modification was felt in a very acute way. This effort is exemplified by both Sanaa, DaM Inv. 20-33.1 and Dublin, CBL Is 1404. Sanaa,

\footnotetext{
71 O. Hamdan, Studien zur Kanonisierung des Korantextes. Al-Hasan al-Bașrīs Beiträge zur Geschichte des Korans, Wiesbaden, 2006, pp. 146-148.

72 Ibn al-Nadim, K. al-Fihrist, ed. R. Tajaddud, Tehran, 1350/1971, p. 9; English transl. by B. Dodge, The Fihrist of al-Nadîm, A tenth-century survey of Muslim culture I, New York/London, 1970, p. 11. Y. Eché (Les bibliothèques publiques et semi-publiques et semi-publiques en Mésopotamie, en Syrie et en Egypte au Moyen Age, Damascus, 1967, p. 18) suggested to identify him with an individual mentioned by al-Sam‘ānī (K. al-ansāb, ed. Hyderabad, t. XII, 1400/1981, p. 284).
} 
DaM Inv. 01-29.2 and Kairouan, Musée des arts islamiques, R 38 go a step further: the frame comes as a complement to this search for a "closed" or "protected" text. Although this element could be seen as the ultimate solution in the search for a regularised justification, both copies still use line-end fillers within the frame.

Three large copies of the Qur'an which may be related to the previous examples may be briefly mentioned here. Two leaves or fragments from a mushaf have been published as Umayyad, one by Marcus Fraser and Will Kwiatkowski,73 and the other one by Yasin Dutton. ${ }^{74}$ The latter author disclosed with his study the results of a $\mathrm{Cl}_{4}$ analysis of the parchment which he summed up in the following way: "it is most likely that the parchment was made between $\mathrm{AD} 609$ and $\mathrm{AD} 694 . " 75$ These dates are actually very similar to those obtained in the analysis of both Sanaa, DaM Inv. 20-33.1 and Kairouan, Musée des arts islamiques, $\mathrm{R} 38$ and support this attribution.

However, in this case again, the $\mathrm{C}_{4} 4$ data need to be qualified. The authors only knew the manuscript through an isolated folio and pictures of other folios kept in Baghdad. Much more material has however been preserved in Istanbul. The 122 folios of the manuscript Istanbul, TIEM, Env. $5^{1}$ and 53 I have been able to examine cursorily exhibit characteristics which do not agree completely with a date in the Umayyad period. Their structure, from a codicological point of view, would rather support a date in the early Abbasid period. The volume is a plano copy, which means that each folio is a full sheet of parchment, like the group of 12-lines-to-the-page manuscripts such as Paris, BnF Arabe $324 \mathrm{c}$ which I suggest to relate to the production of large mușhafs under al-Mahdi's rule, with strong propagandistic motives. ${ }^{76}$ For its part, the illumination does not seem to rely on the Umayyad repertoire which has been analysed here.

Another fragment from a large copy $(43 \times 34 \mathrm{~cm})$ was kept in the Great mosque in Damascus (fig. 44). On each page, a rope surrounds the text. This frame recalls the manuscripts Sanaa, DaM Inv. 01-29.2 and Kairouan, Musée des arts islamiques, $\mathrm{R}_{3} 8$, but in this case the rope stands alone instead of being a component of the frame. Another difference with the other two Quranic copies

\footnotetext{
73 M. Fraser and W. Kwiatkowski, Ink and gold. Islamic calligraphy, Berlin-London, 2006, pp. 18-21.

74 Y. Dutton, An Umayyad fragment of the Qur'an and its dating, Journal of Qur'anic Studies 9-2 (2007), pp. 57-87.

75 Ibid., p. 64.

76 F. Déroche, Of volumes and skins (Part II). The Qur’anic manuscripts of al-Mahdi, in Iraj Afshar Festschrift (forthcoming).
} 
is the ornament based on vegetal components which develops from each of the corners of the frame and recalls a similar although simpler ornament in the Rabbula Gospels. ${ }^{77}$ The 25 lines of text to the page on this manuscript are more in accordance with the earlier examples, for instance the Fustat codex.

The alif has a short crescent shaped lower return and the mim, nün and $h \bar{a}^{\prime}$ are closer to the B group. ${ }^{78}$ The two horizontal strokes of the $k \bar{a} f$ are almost equal in length, a letter shape which was already in use at an early date. ${ }^{79}$ The orthography is close to the scriptio plena as represented by the Cairo edition. $Q \bar{a} l a$ and $q \bar{a} l \bar{u}$ are systematically written in this way and shay' appears in the "modern" orthography, without alif. However, the copyist hesitates about the plural 'iba ad: in sura 37, it is written defectively in verses 122 and 171, for instance, but in scriptio plena in verses 111, 160 or 169 . In quite a few instances, the long $/ \bar{a} /$ is not indicated, for instance in $f \bar{c} i l$ forms. The basmala is marked as a verse, the groups of five and ten verses are indicated respectively by a yellow $h \bar{a}$ ' and by a round ornament with a red abjad letter in its centre. At the end of each sura, in red ink, the total of its verses is indicated in abjad within a rectangle, followed by its title and number of verses, in words, introduced by khätimah sura. A decorated band separates it from the next sura. These headbands are constituted by the repetition of a compartment with simple patterns reserved on red, green and yellow.

The date of the manuscript is problematic. Was it still produced under the Umayyad dynasty or is it an early Abbasid muṣaf? The same question can be asked about the Qur'anic manuscript, which was kept in Katta Langar. ${ }^{80}$ This

77 See C. Ceccheli, G. Furlani and M. Salmi, op. cit., pl. 3a; M. Bernabo et al., op. cit., 2008, pl. IV-V.

78 F. Déroche, op. cit. (1983), pp. $3^{8-39}$ and pl. X-XII; id., op. cit. (1992), pp. $35^{-36}$ and $3{ }^{8}-39$; A. George, op. cit., p. 150.

79 See ch. 2.

80 De Bagdad à Ispahan. Manuscrits islamiques de l'Institut d'études orientales, filiale de Saint-Pétersbourg, Académie des sciences de Russie, Paris, 1994, pp. 84-85, no 1: E. Rezvan, The Qurān and its world: VI. Emergence of the canon: the struggle for uniformity, Manuscripta Orientalia 4-2 (June 1998), pp. 23-26 and 28-46; F. Déroche, Note sur les fragments coraniques anciens de Katta Langar (Ouzbékistan), Patrimoine manuscrit et vie intellectuelle de l'Asie centrale islamique. Cahiers d'Asie centrale 7 (1999), A. Muminov, F. Richard and M. Szuppe eds., Tachkent-Aix-en-Provence, 1999, pp. 65-73 and pl. VII; E. Rezvan, Yet another "Uthmanic Qur'ān" (on the history of manuscript E 20 from the St. Petersburg branch of the Institute of Oriental Studies), Manuscripta Orientalia 6-1 (March 200o), pp. 49-68; id., On the dating of an “Uthmānic Qur’ān” from Saint Petersburg, Manuscripta Orientalia 6-3 (September 2000), pp. 19-22; id., New folios from the 
mușhaf, of which the largest part is kept in Saint Petersburg, Institute of Oriental Studies, E 20, is written in B I style on large vertical format parchment folios $\left(5^{2} \times 3^{2} \mathrm{~cm}\right)$. The sura ornaments are very different from what has been seen before - and may well have been added later. The results of a C14 dating of the parchment are not precise enough, but they suggest a date in the second/eighth century. 81

To this list of problematic manuscripts of the second/eighth century can be added a copy of the Qur'an attributed to 'Uthmān and kept in the Topkapı Saray Library. ${ }^{82}$ The manuscript formerly H.S. $194,{ }^{83}$ now $44 / 32,{ }^{84}$ was in Cairo whence Mehmet Ali sent it to Istanbul as a gift to the Ottoman sultan in $1811 .{ }^{85}$ The text is almost complete on 408 folios measuring $46 \times 41 \mathrm{~cm}$, with most of the time 18 lines to the page. Some folios are probably later replacements. The quires are mostly quinions, with a few quaternions (for instance f. 95-102 or f. 294-301). The parchment sides follow the dominant sequence, that is to say that a quire starts with the hair side as first recto, all the bifolios being arranged in the same position. ${ }^{86}$ Sides of the same nature are facing each other only in the middle of the quire or at the juncture between two quires.

The script can be related to group C, like Kairouan, Musée des arts islamiques $\mathrm{R} 38$. The final or isolated $k \bar{a} f$ is usually written with two horizontal strokes of equal length, but the copyist(s) sometimes elongate(s) the lower stroke when he needs to occupy more space, for instance on f. 80a, l. 2 or $98 \mathrm{a}, 1.12 .{ }^{87}$ Final $q \bar{a} f$ is usually quite conspicuous, with a long tail interfering with the line(s) below. The scriptio plena of $q \bar{a} l a$, 'iba $\bar{a}$ and 'adhāb is dominant. Shay' is written without alif, but the "three denticles" orthography is still in use in bi-āyāt. It should also be noted that 'alā is written with an alif mamdūda.

The verses are divided by small circles or crude rosettes. Tayyar Altıkulaç distinguished three types, one of them being clearly of a later date. ${ }^{88}$ The groups

"Uthmānic Qur'ān" I. (Library for administration of Muslim Affairs of the Republic of Uzbekistan), Manuscripta Orientalia 10-1 (March 2004), pp. 32-41.

81 E. Rezvan, On the dating of an "Uthmanic Qur’ān" from Saint Petersburg, Manuscripta Orientalia 6-3 (September 2000), pp. 19-22.

82 T. Altıkulaç ed., op. cit.

83 F.E. Karatay, Topkapı Sarayı Müzesi Kütüphanesi arapça yazmalar kataloğu, vol. 1, Kur’an, Kur'an ilimleri, Tefsirler. No 1-2171, Istanbul, 1962, p. 1, no 1.

84 T. Altıkulaç ed., op. cit. See also K. Small, Textual criticism and Qurân manuscripts, Lanham MD, 2011, pp. 16-17 and fig. $3-4$.

85 Ibid., p. 73 .

86 F. Déroche et al., op. cit., pp. $74-76$.

87 In both cases, the other shape is found on the next line (see f. 80a, l. 1 and f. 98a, l. 11).

88 T. Altıkulaç ed., op. cit., Plate 2. 
of five and ten are marked by more elaborate circles: here again, two types are most probably original and a third of the same restoration as above. ${ }^{89}$ There are specific devices indicating the groups of hundred verses. ${ }^{90}$ The basmala is marked as a verse.

The suras are separated by headbands containing elements which can be related to an Umayyad iconography. This is, for instance, the case of the scrolls, often schematic (e.g. f. 401 a), most notably of an example where the undulating twig is associated with a vase (f. 109 a).${ }^{91}$ On f. 383 b, an arrow occupies the space left by the last word of sura 71 on 1.18 and recalls those of the manuscript Kairouan, Musée des arts islamiques, $\mathrm{R} 38$. Architecture is quite conspicuous in the manuscript: many headbands contain simple depiction of arcades ${ }^{92}$ which are probably inspired by earlier Umayyad illuminations, but their rendition is closer to the sura ornaments of the Abbasid fragment Paris, BnF Arabe $324 \mathrm{c}$. The last opening with text has been preserved (f. $407 \mathrm{~b}-408 \mathrm{a}$ ). The last suras are inscribed within a circular shape, recalling the first folio of $\mathrm{R} 38$, but the illumination is barely legible. The basmala of suras 111 and 113 is written above the circle, in a separate setting. The date of this mușhaf remains unclear. It is without any doubt a copy of the second/eighth century which is related to the Umayyad tradition. ${ }^{93}$

Drawing a clear cut division between the Umayyad period and the beginnings of Abbasid rule proves particularly difficult as far as manuscript production is concerned. The tumultuous fall of the Umayyads was perhaps also not the most auspicious time for the production of manuscripts and the decline in revenues for the state (or the necessity to spend them on other expenses) had some effect on such big projects as exemplified by the first five manuscripts. However, script styles and illumination did obviously not change overnight in the wake of the Abbasid revolution and some of the features of the Umayyad muṣhaf lingered on for some time. ${ }^{94}$ I would therefore more cautiously speak of an Umayyad tradition - rather than strictly Umayyad manuscripts - when dealing with copies which might be dated to the middle of the second/eighth century, unless some elements clearly invite the contrary.

\footnotetext{
89 Ibid.

$90 \quad$ Ibid., Plate 3 .

$91 \quad$ See detail on pl. 4.

92 See f. 47a, 253b, 292a, 332b, 367a, 373b, 397a. A detail is reproduced ibid., pl. 4 .

93 The muṣhaf attributed to 'Alī b. Abī Ṭālib kept in the Great Mosque in Sanaa belongs to the same typology.

94 See for instance some details of the illumination of Paris, BnF Arabe $324 \mathrm{c}$ (see F. Déroche, forthcoming).
} 
The copies which have been examined should not hide the fact that most of the late Umayyad mușhaf production was of smaller format and still has to be identified. A few examples on which I commented at the end of the previous chapter may belong to this group. The $\mathrm{O}$ I script was probably still in use in some circles or for smaller copies and mușhafs in one of the most regularised varieties of hijäzi style may have been transcribed at that moment. Other fragments to which I shall now turn briefly could also have been produced during the end of the Umayyad period. The copyists were certainly also transcribing the Qur'an in other styles, notably those with the final $k \bar{a} f$ with two branches of the same length. This may be the case of Istanbul, TIEM ŞE 80, a fragment in the Damascus collection containing 62 folios measuring $25,4 \times 28,2 \mathrm{~cm}$, with 21 or 22 lines to the page. ${ }^{95}$ The writing surface is rather constant $(21,7-22 \times 24-$ $25 \mathrm{~cm}$ ), probably because of a frame ruling in brown ink. Part of what has been preserved (f. 53-62) is a later replacement on paper. The original parchment folios (f. 1-52) are written in B Ib style, without vowel signs and few diacritical marks. The verses are separated by columns of oblique dashes in brown ink (1.1.1) and the groups of ten verses are indicated by a red circle surrounded by dots (1.A.II). Next to very simple sura ornaments, a few (a scroll with flowers and leaves, a palm tree, etc.) recall Umayyad models. The paired foliages and the bulbous termination of the headband separating sura 71 and 72 (fig. 45) are clearly related to an ornament found in the Damascus codex (fig. 21). The binding, decorated with a central six-pointed star inscribed in a circle, could be the earliest specimen of a Qur'an binding of Type I. ${ }^{96}$

The fragment Tübingen, UB MaVI 165 could be an example of more common copies of this period (fig. 6). ${ }^{97}$ The seventy-seven parchment folios were bought in Damascus by the middle of the nineteenth century by the Prussian consul Johann Gottfried Wetzstein. They measure $19,5 \times 15,6 \mathrm{~cm}$ and are written with 18 to 21 lines to the page (writing surface: $16,3 / 17,3 \times 12,5 / 13,3 \mathrm{~cm}$ ). The script can be defined as a variety of B Ia, close to that of Saint Petersburg, IOS E 20. The verses are separated by groups of three dashes. At the end of the suras, groups of six dashes are sometimes repeated in order to fill the end of the

95 A few more leaves are scattered in the collection.

96 See A.S. Demirkol et al., 140o. Yllında Kur'an-ı kerim, Istanbul, 2010, pp. 148-151. For Type I binding, see F. Déroche et al., op. cit., pp. 286-289.

97 M. Weisweiler, Universitätsbibliothek Tübingen. Verzeichnis der arabischen Hanschriften II, Leipzig, 1930, p. 125, $\mathrm{n}^{\circ}$ 161. R. Paret (Besonderheiten alter Koranhandschriften, in Studien zur Geschichte und Kultur des Vorderen Orients, Festschrift für B. Spuler zum siebzigsten Geburtstag, H.R. Roemer and A. Noth eds., Leiden, 1981, p. 317, 319 and 320) suggested that it is the third quarter of the Qur'an. 
line. Between the suras, ornaments have been drawn in a dark brown ink and are irregularly enhanced by touches of red. With the exception of the frame with a compartment decoration on $\mathrm{f}$. 33a, they develop freely as in some of the illuminations of the Damascus codex. Some of them, for instance on $\mathrm{f}$. 11, may derive from the acanthus sheaths as on f. 6 (sura 19) of the Fustat codex.

Von Bothmer's pioneer work on the manuscript Sanaa, DaM Inv. 20-33.1 has led to the identification of a group of magnificent copies produced under official patronage. They reflect a major change in the techniques involved in their production, as well as a new vision of the Qur'an as a book. Were official "scriptoria" in charge of the preparation of such volumes? The similarities between them point to a control over their appearance, but their idiosyncrasies prevent from considering that they were produced by a well-established team. Some amount of team work was certainly involved, but probably in a more informal way. The ornamental repertoire evolved: some components inherited from the Late Antique tradition are still present, especially in the Qur'anic manuscripts discussed in the first part of this chapter, but geometrical compositions and highly stylized vegetal shapes played an increasing role in the last examples. Are we still dealing with Umayyad manuscripts? On this point, more research is needed in order to ascribe them confidently to this period or to the beginning of Abbasid rule. 